$\begin{array}{ll} & \text { Etnográfica } \\ \text { etnográfica } & \text { Revista do Centro em Rede de Investigação em }\end{array}$

Antropologia

vol. 19 (1) | 2015

Vol. $19(1)$

\title{
De cara com a violência: um exercício de escrita etnográfica
}

Facing violence: an exercise of ethnographic writing

\section{Silvia Monroy}

\section{(2) OpenEdition \\ Journals}

\section{Edição electrónica}

URL: https://journals.openedition.org/etnografica/3874

DOI: 10.4000/etnografica.3874

ISSN: 2182-2891

\section{Editora}

Centro em Rede de Investigação em Antropologia

\section{Edição impressa}

Data de publição: 1 fevereiro 2015

Paginação: 5-27

ISSN: 0873-6561

\section{Refêrencia eletrónica}

Silvia Monroy, «De cara com a violência: um exercício de escrita etnográfica», Etnográfica [Online], vol. 19 (1) | 2015, posto online no dia 06 março 2015, consultado o 11 fevereiro 2022. URL: http:// journals.openedition.org/etnografica/3874 ; DOI: https://doi.org/10.4000/etnografica.3874

\section{(cc) (i) \&}

Etnográfica is licensed under a Creative Commons Attribution-NonCommercial 4.0 International License. 


\section{De cara com a violência: um exercício de escrita etnográfica}

\section{Silvia Monroy}

O presente artigo é um experimento de escrita sobre os efeitos da violência a partir do contato que mantive com três mulheres durante a pesquisa de campo realizada entre 2009 e 2010 em Urabá, Colômbia. Ao explicitar minhas experiências com elas, identifico quatro tipos de relatos: inacabado, testemunhal ou biográfico, prosa e testemunhal distanciado. As três seções do artigo estão vinculadas às interações no campo e a certos aspectos dos encontros intersubjetivos que ligam efeitos da experiência violenta com a forma dominante de conceber o tempo na região, isto é, a precedência do presente.

PALAVRAS-CHAVE: Urabá, Colômbia, escrita etnográfica, violência.

Facing violence: an exercise of ethnographic writing - This article is a writing experiment on the effects of violence, starting from the way I presented myself to three local women during my fieldwork in Urabá (Colombia) between 2009 and 2010. By describing my experiences with them I identify four possible types of narratives: unfinished stories, testimonial or biographical ones, prose, and distanced testimonial account. The three main sections of the paper are bound to the fieldwork interactions and to certain aspects of intersubjective encounters which link some effects of violent experience to the prevailing conception of time in the region, i.e., the precedence of the present.

KEYWORDS: Urabá, Colombia, ethnographic writing, violence.

MONROY, Silvia (silviamonroy@gmail.com) - Departamento de Antropologia, Universidade de Brasília, Brasil. 


\section{EM 2008, AINDA ESTAVA LONGE DE IMAGINAR QUE A MINHA PESQUISA} de doutorado seria realizada em Urabá (Colômbia), presente nos relatos da minha infância e adolescência devido às atrocidades do meu país como um ponto vermelho em um mapa, um ícone. ${ }^{1}$ Contudo, várias perguntas já haviam surgido a partir do desejo de confrontar a violência como tema de investigação: como seria o processo de pesquisa e meus relacionamentos em campo, levando em consideração que as minhas inquietações sobre a violência nasceram do fastio, da frustração e da dor de várias gerações, incluindo a minha, nascidas no vórtice das "guerras" ou durante os curtos períodos de cessar-fogo? Conseguiria vencer o medo, a desconfiança e o silêncio de meus interlocutores, que são também uma parcela do meu medo, da minha desconfiança e do meu silêncio? Conseguiria sobreviver a esta empreitada com uma compreensão que aliviasse a minha declarada incompreensão da violência?

Estas perguntas persistiram durante o ano de trabalho de campo em Urabá; as possíveis respostas adotaram matizes que somente consegui avaliar, de uma maneira incipiente, durante a fase subsequente, em Brasília. Defrontei-me, graças à escrita, com outra questão: como transmitir o vivido? Certamente, o exercício artesanal da escrita etnográfica permitiu que eu repensasse minhas experiências e as transformações desencadeadas em mim, incluindo a minha subjetividade de pesquisadora. A escrita, portanto, formou, espontaneamente,

l Urabá é uma região localizada na fronteira com o Panamá. Com aproximadamente 600 mil habitantes hoje, reconhece-se pela instalação da agroindústria bananeira a partir da década de 1960 e também por ter um caráter triplo de fronteira. Além de ser fronteira internacional, com conexão marítima direta pelo Mar do Caribe e indireta pelo Oceano Pacífico através de rios e estradas rudimentares - que facilitam o tráfico ilegal de contrabando, armas e drogas -, é uma fronteira interna regional que liga as dinâmicas de três departamentos: Chocó, Antioquia e Córdoba. Simultaneamente, é uma fronteira étnica, pois ali confluem grupos indígenas - embera, tule e zenú -, populações negras e outras populações provenientes de regiões andinas do país. As guerrilhas do Ejército de Liberación Nacional (ELN) e do Ejército Popular de Liberación (EPL) entraram em Urabá em 1966, e as Fuerzas Armadas Revolucionarias de Colombia (FARC) em 1969 (García 1996), mas o conflito fez-se brutal a partir do final da década de 1970, quando a mudança de estratégia concentrou-se nos sindicatos, infiltrados pelas guerrilhas. Morreram milhares de trabalhadores bananeiros acusados de pertencer ou colaborar com o sindicato ou grupo armado oposto. Exército e polícia combateram suas ações, mas a conflagração foi iminente no meio do terror anticomunista ainda vivo, ao qual se acrescentou o extermínio local e nacional do partido político de esquerda Unión Patriótica (UP). Simultaneamente, na década de 1980, os carteles do narcotráfico criaram exércitos privados que, junto com iniciativas contrainsurgentes de comerciantes, fazendeiros, donos de gado, políticos e militares, desembocaram, na década de 1990, nas Autodefensas Campesinas de Córdoba y Urabá (ACCU) e nas Autodefensas Unidas de Colombia (AUC). Dessa maneira, os assassinatos seletivos e os massacres constituíram o reflexo de uma nova virada no conflito na Colômbia com a incursão dos grupos paramilitares confederados. Registraram-se em Urabá, por exemplo, 96 massacres na década de 1990, um por mês entre 1992 e 1993, e um a cada vinte dias entre 1994 e 1995. O extermínio também pode ser lido nos 2950 assassinatos perpetrados, entre 1995 e 1997, numa região com aproximadamente 500 mil habitantes naquele período (Suárez 2007). No início de 2010, foram registradas 17 mil vítimas, correspondentes à época de consolidação do controle paramilitar (1997-2005) em Urabá. 
uma tríade junto com as categorias violência e tempo. Essa tríade permitiu que eu plasmasse, em relatos, alguns dos percursos que podem ser desenhados a partir das noções de vida, sobrevivência, sobrevida, morte, agonia, silêncio, bloqueio, pesadelo e luto vividas em Urabá.

Foi somente durante a fase de escrita que o trio fundamental do pesquisador que fala acerca da violência, identificado por Daniel (1996) a partir de sua pesquisa no Sri Lanka, fez sentido para mim. Esse conjunto violência/escrita/tempo está conectado à tríade básica proposta por Peirce (1955). Para Peirce, existem três modos de ser: o da possibilidade qualitativa (First), o do fato concreto (Second), e o da lei que governará fatos no futuro (Third). O First é algo peculiar e idiossincrático, e é dominante no sentimento. Já o Second é um evento, algo que acontece aqui e agora, quando a atualidade é algo bruto. Finalmente, o Third se refere à convenção, à modalidade que rege os fatos do futuro, à lei como força ativa.

Escrever acerca da violência é desafiador porque o fato bruto da pesquisa de campo (Second) precisa ser transformado na escrita referencial do mundo acadêmico (Third). Ou, em palavras mais singelas, a força do evento vivido ou presenciado, especialmente quando se refere à violência, precisa se transformar em texto sem que se banalize a dor e a experiência. O momento que corresponde à violência não pode ser negado nem sacrificado, pois reproduziria uma mesma convenção com relação a um objeto já distanciado (Daniel 1996). Como, então, transformar o Secondness em um texto referencial que contenha os sentimentos que são expressos tanto no dito como no silenciado?

Este é o desafio deste artigo. A minha aproximação no texto e os encontros intersubjetivos que destaco nos relatos reivindicam a importância de plasmar etnograficamente a tênue fronteira entre os âmbitos do dito e do feito (Peirano 2001 ), e do saying e showing (Das 2007). Procuro, então, não pressupor que a linguagem é mera representação, ou que a comunicação está somente centrada no que é verbal. Gestos, palavras, silêncios precisam ser contemplados na escrita etnográfica de forma sensível.

Parto da maneira como me identificava em Urabá e dos princípios que fui aprendendo com três mulheres da região: Nina, Mônica e Andrea. As três seções do artigo estão vinculadas, portanto, às nossas interações. Um segundo objetivo consiste em identificar possibilidades de expansão das narrativas criadas nos encontros. Para este fim, peço emprestados os quatro tipos de relato inspirados em Crapanzano (1994). O relato inacabado (1), que em alguns casos tem o caráter do déjà raconté, compreende a narração de histórias pessoais que adotam o tom de história oficial, com direito a conselhos e lições para a audiência ou para o interlocutor. $\mathrm{O}$ relato testemunhal ou biográfico (2) está vinculado a uma narração saturada de imagens; é composto por muitos episódios, o que, eventualmente, impede a negociação com o interlocutor, pois o relato é tão denso que ou se aceita ou se rejeita tudo. Já a prosa (3) é definida 
como a melancolia da linguagem; as emoções se desprendem da fronteira entre a prédica e a conversa. Abrange histórias que implicam uma troca emotiva que pode ser entendida dialogicamente. A prosa pode ser definida também, segundo Trajano (1984), como um momento de máxima expressividade, não necessariamente verbal, com gestos e silêncios que tomam conta da ação em andamento. ${ }^{2}$ A prosa abre uma via de acesso que permite atingir um alto grau de proximidade às experiências do outro, ou seja, envolve o potencial de aprender com que elementos a subjetividade, as emoções e os sentimentos desse "outro" são elaborados. Por fim, o relato testemunhal distanciado (4) diferencia-se do biográfico porquanto há possibilidades de negociação com o interlocutor. Veremos como, em muitos casos, o medo e o terror tornam-se recursos retóricos da construção do próprio relato.

\section{CHEGADA E ESTRATÉGIA DE IDENTIFICAÇÃO BÁSICA}

Uma das primeiras providências que tomei ao chegar a Urabá, informada por pessoas que haviam morado lá e por outros pesquisadores que trabalham em regiões marcadas pela guerra, foi apresentar-me da forma mais clara possível, sem deixar muito espaço para dúvidas, isto é, contar a mesma versão de quem eu era, o que eu estava fazendo, quais meus objetivos, de onde vinha, minha vinculação institucional, minha profissão, meu estado civil. ${ }^{3}$ Essa foi uma parte fundamental do processo de entrada no campo. A estratégia funcionou como acesso, mas não impediu que enfrentasse ambiguidades e suspeitas. Ser uma mulher de mais de 30 anos sem filhos, por exemplo, foi um dos aspectos mais obscuros para meus interlocutores. Alguns achavam que eu era homossexual ou, em outros casos, fui enquadrada dentro do estereótipo "guerrilheira", pois é comum ouvir que as guerrilheiras não podem ter filhos já que a maternidade é interditada pelo envolvimento na "guerra".

Por outro lado, narrar para todo mundo a mesma história durante o ano que durou o trabalho de campo tornou-se extremamente desgastante: tudo

2 Trajano (1984) antecipa uma classificação próxima à de Crapanzano (1994). Os encontros etnográficos, na sua visão, podem propiciar diálogos, conversas, prosas e quase-prosas. O diálogo é definido como uma situação que busca evitar os mal-entendidos. Baseia-se em perguntas formuladas numa via só. Na conversa, por sua vez, está implícita uma troca de ideias, isto é, circula um maior número de informações entre os participantes. Na conversa já estão presentes olhares provocadores, sorrisos intrigantes, gestos agressivos e silêncios. A diferença entre diálogo e conversa é que, na segunda, as informações e mensagens tendem a fluir nas mais diversas direções. A conversa pode ser uma fase preparatória da prosa, mas, em certos momentos, a prosa gera conversas.

3 Estou me referindo a colegas vinculados a universidades, centros de pesquisa e ONG que têm trabalhado em regiões com uma tradição de conflito armado crônico. Contudo, seus "conselhos" não aparecem registrados em textos acadêmicos. Pelo contrário, foram comentários feitos em tom de advertência, antes de viajar a Urabá, e com um sigilo que busco, em larga medida, descortinar no presente artigo. 
começava do zero diariamente. Esta demanda, depois compreendi, não se tratava de uma estratégia para proteger a minha vida, mas a forma de meus interlocutores se protegerem de meus possíveis envolvimentos e, por conseguinte, protegerem a sua vida.

Assim, a minha vida em Urabá recomeçava diariamente, ou seja, minha existência social não era cumulativa. Meus percursos e relacionamentos iam sendo avaliados e vigiados constantemente. De fato, quando pensei já haver estabelecido uma relação de mão dupla com algumas pessoas, ao retornar de uma ausência em que demorei mais do que havia antecipado, encontrei-as surpreendentemente fechadas. Minha demora havia provocado suspeita e desconfiança, e tive que aguardar alguns dias para o retorno dos vínculos anteriores. Vale a pena notar, no entanto, que a confiança nunca foi definitiva, nunca foi total.

Fui cautelosa, depois de advertida, acerca de algumas perguntas como, por exemplo, sobre os "donos" de fazendas e plantações, empresas, lojas e outros empreendimentos. Contornei esta dificuldade elegendo temas como orientações religiosas e me envolvendo como voluntária em vários projetos. Assim, consegui percorrer Urabá como voluntária do fundo rotativo Banco de la Esperanza, como cinematografista ad hoc ou como professora de português numa paróquia.

Em 2009 a 2010, a região estava sob controle das estruturas legadas pelos grupos paramilitares após a desmobilização das AUC. ${ }^{4}$ Esse controle, portanto, limitava meus percursos na região. Como os efeitos do domínio do território por parte de grupos armados são mais evidentes nas áreas rurais - especialmente naquelas regiões que têm plantios de coca ou que são enclaves-chave para as rotas do narcotráfico e contrabando de armas -, a pesquisa limitou-se aos povoados urbanos de Urabá. Transitar nas áreas rurais localizadas ao sopé das serras ou cobrindo terras montanhosas, consideradas área de influência guerrilheira, das Fuerzas Armadas Revolucionarias de Colombia (FARC), foi claramente desaconselhado; era inviável.

Nos encontros, havia uma sequência que se tornou rotina, mesmo dentro das atividades dos voluntariados: começava com a narração padrão da minha identificação; em seguida, o relato de vida das pessoas, cujos desdobramentos pareciam não se esgotar. Não estava necessariamente em questão a total franqueza porque, como sempre, os relatos podem ignorar, camuflar ou dri-

4 Os blocos das Autodefensas Unidas de Colombia (AUC) que operavam em Urabá - Bloco Bananero y Bloco Élmer Cárdenas - começaram o processo de desmobilização de dois mil membros da organização, entre 2004 e 2006, sob a tutela da Lei de Justiça e Paz (Lei n. ${ }^{\circ}$ 975, de 2005). Esta lei facilita os processos de paz e incorporação individual e coletiva à vida civil de membros de "grupos armados ilegais à margem da lei”, além de garantir os direitos à verdade, à justiça e à reparação das vítimas, tanto pela via administrativa como judicial. É um processo polêmico, pois muitas bases armadas das AUC não foram desestruturadas e algumas delas têm se reciclado em novos grupos armados. Além disso, os trâmites da lei não têm implicado o cumprimento dos compromissos de verdade, justiça e reparação. 
blar as partes interditadas, no caso, especialmente devido à dor ou pelo temor latente. O local de nascimento, a idade, as razões para chegar ou para viver em Urabá eram os assuntos básicos.

A maioria dos primeiros encontros não foi gravada, mas pontuada de algumas anotações que eu fazia durante as conversas. As descrições e os comentários com maiores detalhes, eu os realizava ao final do dia, quando redigia o diário de campo. Alguns encontros não tiveram continuidade. Outros, como é o caso de Nina e de Andrea, tornaram-se o eixo de muitos de meus percursos em Urabá. Considero-os importantes não apenas pelas entrevistas realizadas, isto é, devido à parte informativa e referencial, mas principalmente pela profundidade do elo estabelecido e pelos conteúdos de nossas reflexões acerca da vida, de nossas vidas, da sobrevivência e da morte.

\section{Nina}

Conheci Nina em uma reunião de "viúvas vítimas da violência" na tarde de um sábado. Naquele encontro, apresentei-me ao grupo de mulheres usando a mesma retórica de sempre. Do grupo de quase quarenta mulheres presentes, às quais dei meu número de celular, foi Nina quem me telefonou algumas semanas depois. Disse-me que precisava dividir com alguém sua história. Marcamos um encontro, o primeiro deles, para minha surpresa, na casa dela. Nina queria que eu a ajudasse, pois não sabia como fugir do controle de uma pessoa que a estava atormentando. A minha surpresa inicial, acompanhada das explicações acerca de meus limitados poderes para resolver sua situação, foi abrindo espaço a uma impressionante narração, nas entranhas da sobrevivência em Urabá. No meu diário de campo, após alguns encontros com Nina, escrevo como resultado de um instante de prosa o seguinte:

"La pregunta con Nina no es más si ella quiere vivir. La pregunta es por qué busca la muerte. Hoy le pregunté: 'Nina, ¿̇usted quiere vivir?' Ella me respondió con la mirada esquiva y en voz baja: 'Tal vez'. Luego, de la nada, me salió la pregunta: '¿Usted quiere morir?’ Ella me respondió con más firmeza: 'No sé, pero creo que esa pregunta es más difícil que la primera'.”

O desengano de Nina, após o assassinato de seu marido, em 2002, e a morte acidental de sua única filha, em 2004, é uma dor que nasce de um luto no qual as definições de vítima-algoz são ainda difusas, tais como suas trajetórias. O caso de Nina é mais complexo porque se tornou amante do assassino de seu marido. A sobrevivência dela estava diretamente vinculada à relação com seu algoz. Ele era o algoz que ainda decidia, ou que ainda não havia decidido, se ela poderia viver ou se deveria morrer. Sua sobrevivência ficava a meio caminho entre a vida e a morte. Em parte por isso, meus questionamentos pareciam provocar nela uma resposta na qual a possibilidade de viver e as chances de 
morrer estavam nas mãos de seu algoz, e não nas dela. Porém, a pergunta pela vontade de viver ainda pertencia a ela e, por isto, sua resposta foi um contido "talvez". A morte, por seu turno, é uma questão mais densa, uma vez que não é uma decisão dela, mas uma condição atual de sua sobrevivência. Uma frase de Nina resume bem esse paradoxo: "Él no me da buena vida, ni me la deja vivir".

Durante nosso primeiro encontro, ela policiou-se para não falar o nome "dele"; para mencioná-lo usou a expressão "ese señor". Em situações posteriores, ela começou a falar com mais confiança, usando um apelido comum dentro do casal, "El gordo". Em algum momento, mencionou a "chapa" - nome de guerra - usada por ele dentro do grupo paramilitar, mas, nesse caso, fui eu que tomei a decisão de esquecer essa informação, reproduzindo o mecanismo que a convivência em Urabá tinha me ensinado. Em um dos nossos últimos encontros, Nina mostrou-me uma fotocópia da carteira de identidade de "El gordo", guardada com zelo, como se fosse uma garantia que poderia permitir identificar o responsável pela sua morte, tão próxima e, às vezes, tão procurada por ela. Naquela ocasião, eu também fiz questão de não guardar as informações da carteira de identidade, embora tenha visto esse nome em jornais. Esses anúncios ativaram uma parte da minha memória que, no entanto, permaneceu desativada durante minha permanência na região. Tomei esta decisão de uma forma espontânea a partir dos momentos prosa - ponto limite na percepção do lugar -, em grande medida, para manter o laço com Nina. Hoje em dia, reconheço a minha atitude. A minha relação com ela foi uma constatação de uma das leis tácitas da sobrevivência em Urabá: "Entre menos sepa lo que está pasando, mejor para usted".

A certeza de Nina de que o assassino de seu marido é "El gordo", demonstrada ainda no início de nossa primeira conversa, foi se tornando mais lacônica nas visitas posteriores, nas quais nós duas começamos a evitar a questão. Eu somente perguntava se "ele" tinha aparecido; se havia alguma novidade, ou seja, se Nina tinha conseguido se libertar dele. Em uma ocasião, ela revelou o local onde ele estava escondido, pois a guerra pelo território estava excluindo o grupo ao qual ele pertencia, uma banda emergente ou BACRIM. ${ }^{5}$ Isso fazia com

5 Sigla relativa à categoria bandas criminales (BACRIM) que surgiu durante o último ano (2009-2010) do mandato de Álvaro Uribe como alternativa para legitimar o polêmico processo de desmobilização das Autodefensas Unidas de Colombia (AUC) ocorrido entre 2004 e 2006, e respaldado pela Lei n. ${ }^{\circ}$ 975, de 2005. Como já referido, afirma-se que muitas bases armadas daquela organização não foram desestruturadas e algumas delas têm se reciclado nas BACRIM. No primeiro semestre de 2010, mencionava-se o conflito entre Urabeños, Paisas, Águilas Negras y Rastrojos (Human Rights Watch 2010). Estes grupos dedicam-se ao controle armado dos plantios, laboratórios, rotas e pontos de embarque de cocaína, e ao controle armado de outras atividades como o contrabando e a mineração ilegal. Além disso, estes grupos espalhados pelo país inteiro - em cidades e áreas urbanas - buscam controlar o acesso das populações a bens e serviços, o comércio local e o transporte de passageiros e de carga. Usam como fachada a venda de serviços de proteção e segurança para cometer atos de extorsão vinculados, por sua vez, a ameaças, assassinatos e deslocamentos forçados de população. 
que o dinheiro que ele dava para sua manutenção não estivesse chegando. Nessa situação, o papel de provedor motivava em Nina a busca por uma eventual proximidade, mesmo no exílio dele. O compromisso econômico que garantia uma parte do sustento de Nina era, por outro lado, um aspecto graças ao qual ela conseguia não olhar para ele como seu algoz e, sim, como seu companheiro. Mas quando ela falava de sua perda mais profunda, reiterava que "ele" tinha tirado dela a possibilidade de ter um lar; uma possibilidade que, ao ser amante dele, continuava sendo negada ou, melhor dizendo, a perda continuava sendo reproduzida.

A certeza de Nina sobre o assassino de seu marido, e atual algoz, foi construída mediante uma narração episódica - uma espécie de relato testemunhal ou biográfico, segundo Crapanzano (1994) -, mas a partir de eventos posteriores ao próprio assassinato. Nina disse:

"Después de que lo mataron, ellos se llevaron el techo también. Levantaron todo después. Esa gente cuando hacen una cosa, no dejan nada [...]. Cuando llegaron a matarnos dizque él supuestamente me salvó y se enamoró de mí. Yo lo vi y dije: 'Éste fue el que mató mi marido... la voz, las manos, la boca, el cuerpo, las manos... ¿Por qué me pasa esto? Yo sentía miedo... yo lo he odiado a él por todo. Yo digo que lo maten pero cuando uno desea una cosa, no pasa. Él dice que yo estoy con él por venganza... uno ve el perfil de la persona y se acuerda. Después, él jamás me dejó en paz."

\section{E continuou:}

"Un día en una fiesta que hubo en el barrio, estábamos bailando y me dice: '¿Quién cree que le mató su marido?' Yo le dije: 'Ustedes'. '¿Nosotros quiénes?' Las Convivir o las AUC. Él dijo: ‘Nosotros no fuimos'. 'Ustedes fueron'. Desde eso yo les digo que fueron ellos. Ellos mataron a un sobrino mío; yo digo ellos porque ellos lo iban a matar en la Comuna 13 [em Medellín]. Entonces, estos supuestamente lo pusieron a trabajar aquí [em Urabá], a sapiar [delatar] y a trabajar, y después lo mataron. El sobrino me decía que ellos le decían: 'Mire, nosotros le matamos al marido y ella está con nosotros'. Él ["El gordo"] le decía eso a la gente... a mis cuatro sobrinos y a mi hija. Eso era diario.”

Após o assassinato do marido, ela passa a pertencer ao "grupo" do assassino dele. "El gordo" sabe-se o dono desse território e, por essa razão, pode dispor da vida dela. Em inúmeras ocasiões sugeri a Nina que fugisse, mas ela confirmou que a ameaça de morte era extensiva aos seus sobrinhos e a sua mãe, todos moradores do mesmo bairro. Garantiu-me que se ela fugisse, ele não iria descansar até matá-la. Seu maior temor foi resumido na frase: "Ellos todavía 
mandan aquí." Esta resposta constata a impossibilidade de se dissociar território de população em âmbitos mais restritos da vida em Urabá.

A luta pelo território entre bandos estava deixando Nina ainda mais tensa no início de 2010. Disse-me que, quando sentia as motos indo devagar atrás dela, sentia que estavam quase a ponto de disparar. Além disso, ocorreu um episódio envolvendo um órgão do Estado, também no início de 2010, quando fizeram uma batida em sua casa, seguindo as pistas do homem em questão. Quando eu perguntei como ela havia reagido, deixou em evidência outra regra de sobrevivência que, na fórmula verbal empregada por ela, se espera que o interlocutor já saiba. Esse é um recurso correspondente ao relato biográfico distanciado, identificado por Crapanzano (1994). Isto é, existe um uso retórico intermediado por uma relação de longa duração com o medo e com o terror. Nina disse que, quando as pessoas chegam a determinado local com o propósito de assassinar alguém, sempre chegam em grupo ou, geralmente, levam uniformes de algum órgão do Estado. Conforme ela disse, eu já devia saber disso.

Uma das caracterizações mais complexas da história de Nina foi feita pela esposa de "El gordo", vizinha de bairro de Nina. Para ambas, a existência da outra era um fato conhecido, embora nunca pudesse ser explicitado. No entanto, em uma discussão que envolveu as duas, dentro do território controlado pelo amante de uma e pelo marido da outra, a esposa "dele" disse a Nina: "Él está con usted porque él a usted la tiene que matar."

Daniel (1996) afirma que, quando o presente é o tempo dominante, o futuro e o passado fluem através dele, mas esses tempos estão condenados a participar da impermanência do presente. A noção de impermanência permite descrever melhor esse estado de transformações sucessivas, cuja máxima é que o mundo se movimenta apesar dele mesmo. Aquilo que faz o bem hoje pode engendrar o mal amanhã. Os libertadores de ontem podem se converter nos torturadores de hoje, e assim por diante. Na base desta subjetividade, a sobrevivência de Nina continuava pendente quando eu terminei a pesquisa. A questão central aqui é que a impermanência, moldada numa precedência do presente, faz com que o valor da sobrevivência seja mais importante que o valor da vida. A fala da esposa de "El gordo" confirma essa precedência: "ele" somente está com ela para deixá-la sobreviver hoje.

Pelos rumos da própria impermanência, ao escrever sobre Nina, em 2011 , quis saber notícias dela. Consegui falar com sua irmã, porque Nina tinha trocado o número do telefone (aliás, mais uma vez). Porém, em concordância com sua atitude temerária, tinha dado o seu antigo número para sua irmã mais velha, o que, afinal, me permitiu ter notícias dela. Na hora pensei que Nina estava tentando se esconder, apesar de deixar pistas para ser achada. Identifiquei-me relembrando, mais de um ano depois de ter saído de Urabá, minha velha retórica de apresentação. Quando a irmã confirmou quem eu era, 
disse-me que "esse senhor" finalmente tinha deixado Nina em paz. Contou que Nina tinha voltado à chácara da qual foi banida pelos paramilitares quase uma década antes. O território já não é deles, pensei quase concluindo. A irmã de Nina também disse que "ele" ainda não foi pego e, como a impermanência é a base da sobrevivência, um pressuposto difícil de erradicar, "no se sabe hasta cuando", concluiu ela em nossa conversa telefônica.

\section{Mônica}

Os encontros com Mônica foram somente dois. Não desenvolvi com ela um elo tão forte como aconteceu com Nina ou com Andrea. Contudo, o curto diálogo com Mônica, que ela terminou sem aparente razão, revelou certos aspectos acerca da morte que somente alguém com uma experiência como a dela poderia ter.

Mônica é funcionária de um escritório público. É uma mulher negra de 35 anos. A beleza dela chama a atenção de imediato. De fato, durante o segundo e último encontro que tivemos, na casa dela, vi fotos de quando tinha sido miss em um concurso regional de beleza. Na nossa primeira conversa, ela disse que as histórias sobre a violência em Urabá são muitas e diversas. Reconheceu que as pessoas têm se acostumado com a morte violenta, ao ponto de parecer natural, mas garantiu que ela nunca se acostumou com o fato de alguém tirar a vida de outro. Para mim, a essa altura da pesquisa, ouvir falar isso era uma novidade, pois a resposta mais comum era que, se alguém tinha sido assassinado, era porque "alguma coisa tinha feito" ou "alguma coisa devia". A seguir, veio uma declaração reveladora, constituindo uma daquelas viradas etnográficas, daqueles encontros - momentos de prosa, segundo Trajano (1984) - nos quais o antropólogo tem a certeza de ter chegado a outro lugar. O parceiro enxerga-se tão nitidamente ao ponto de não haver dúvidas que manter aquele encontro é a própria finalidade da prosa. Mônica disse-me que ela arrumava "corpos sem vida”. Sem fazer pausas, perguntou, com a mesma graça, mantendo uma postura entre imponente e compassiva, se eu sabia o que era a tanatologia. Eu ainda estava voltando da surpresa que me causou a expressão "arrumar corpos sem vida" quando ela começou a falar em Tanathos, o deus grego da morte. Depois, continuou seu relato bibliográfico fazendo referência ao curso técnico que tinha realizado para aprender a arrumar "corpos sem vida", uma opção de vida para ela, até mesmo depois de ter estudado Ciências Contábeis.

A meu ver, o relato de Mônica sobre seu trabalho como tanatologista tem um correlato depurado na literatura. Foi por um feliz acaso que encontrei o livro El Enterrador, do poeta, dono de funerária e especialista em arrumar "corpos sem vida” Thomas Lynch (2004 [1997]). Mônica e Lynch dialogaram na minha cabeça, e agora no texto. Lynch focaliza o tema "estar morto", inspirado no aparentemente tranquilo e pacato cotidiano de uma cidadezinha no estado de Michigan, local onde é fácil estimar o número de mortos por ano e, 
inclusive, o número de suicidas. Mônica, por sua vez, está localizada no tema "ser assassinado" no contexto de Urabá, o que faz com que o "estar morto", na percepção de Lynch, não seja somente uma espécie de calamidade que afeta a espécie humana e outras, porém uma tragédia social plasmada em um “corpo sem vida".

Poder-se-ia dizer que a incomum resposta de Mônica sobre o não merecimento de uma morte violenta, sob nenhuma condição ou circunstância, tem a ver com as conclusões tiradas a partir de seu ofício. Lynch e Mônica, apesar de ele não falar da morte em um cenário de "guerra", concordam na caracterização do que é um "corpo sem vida”. Aliás, os dois evitam usar o termo "cadáver". Mônica sentenciou durante nossa conversa: "Ahí ya no hay nada, Silvia." Lynch (2004 [1997]: 47), por sua vez, afirma: “[...] los cuerpos de los recién muertos no son desechos ni restos, como tampoco son íconos o esencia pura."

Os detalhes do trabalho de Mônica e Lynch são elaborados por eles a partir desse pressuposto existencial, da definição de "corpo sem vida". Ela, por exemplo, comentou que tinha arrumado 45 corpos, resultado de um massacre, em quatro horas e meia. Explicou, sem mudar sua postura nem o tom de voz - um relato distanciado -, que primeiro é preciso lavar o corpo, tendo a precaução de que cada um permaneça com suas próprias vísceras. Os mortos "naturais", como ela disse, precisam de um procedimento menos complexo. Depois do banho, são abertos alguns orifícios para a saída dos gases. Posteriormente, os dedos, as extremidades e expressão são matizados. O rigor mortis é atenuado. A maquiagem é o seguinte passo. No caso das mortes violentas, os corpos devem ser abertos, os intestinos são separados para que a cavidade abdominal possa ser coberta com camadas de algodão e serragem. Depois, os demais procedimentos relativos às roupas e à expressão facial são realizados.

Ainda que Mônica tenha afirmado que ali não há nada, a integridade, ou melhor, o resgate da integridade do corpo é fundamental, sobretudo para retornar ao universo dos "seres queridos", da família, dos "dolentes". Ali é que existe a morte, segundo Mônica, ali é que existe a dor e sua própria aflição como ser humano. De fato, ela confessou que arruma os corpos, mas faz questão de não ver os familiares do falecido. Além disso, desde que começou a aprender o ofício com um amigo que trabalhava em uma funerária na "época da violência" - os anos 90 -, antes de fazer o curso técnico, desenvolveu uma fobia aos caixões e ainda hoje não consegue ver os mortos dentro deles. Aliás, essa foi uma das poucas ocasiões em que ela usou a palavra "mortos".

Ela resolveu parte da fobia durante uma confraternização, pois o anfitrião, que era dono de uma funerária, guardou alguns caixões no segundo andar desabitado. A certa altura da festa, Mônica subiu para descansar. O local estava cheio de cofres. No andar de baixo, as pessoas estavam no auge da festa; naquele momento, Mônica teve certeza que tinha chegado o momento de tentar vencer o medo. Resolveu, portanto, dormir dentro de um dos caixões da sala. 
Essa experiência, mais do que as recontagens dos corpos sem vida que já embelezou, rendeu a determinação, em vida, de enfrentar a morte na fase de reintegração ao mundo dos vivos. Naquele momento, Mônica colocou-se no lugar do "corpo sem vida" para tentar resolver um dilema criado a partir da precedência da sobrevida e não da vida em Urabá, quer dizer, da precedência da ameaça constante - diária - da morte, ou da vida com validade de um dia. Essa experiência, certamente, contribuiu para que ela se distanciasse do argumento da morte violenta merecida, tão comum naquele contexto.

A questão da integridade do corpo é explorada poeticamente por Lynch, ao selecionar, no entanto, o caso do corpo de uma menina estuprada e assassinada. Um dos empregados da funerária demorou horas no trabalho de resgatar o corpo, não para que a menina se levantasse dentre os mortos, nas palavras do autor, nem para esconder da mãe da criança o que tinha acontecido, mas para resgatá-lo da morte que o assassino quis imprimir nele.

O "corpo sem vida", que é resultado da guerra e do ato de violência, de modo geral, pode ser usado para enviar mensagens diversas ou pode, justamente, carregar as marcas do agressor, do inimigo. Esse não é o foco da minha análise, nem é o foco de Mônica ou de Lynch. Mônica enfatizou a importância do "corpo sem vida" para os familiares, a importância da reintegração, embora o corpo em si já não seja nada. Na rejeição da morte violenta manifestou-se outro medo, declarado por ela durante nosso encontro. Quando perguntei pelos aspectos que mais a tinham perturbado no início de sua prática como tanatologista, ela respondeu: os orifícios deixados pelas balas. Depois que disse isso, Mônica trouxe à tona uma lembrança que a acompanha até hoje: ela presenciou um massacre e ainda hoje, quando dorme, escuta os tiros e fica tremendo. Esse pesadelo constante, mais de 15 anos depois do evento, é um dos efeitos da violência na sobrevivência. No caso de Mônica, foi o seu trabalho com "corpos sem vida" que moldou seus temores de uma forma distinta, assim como sua concepção de vida: "El que está vivo tiene que aprender a vivir." Ela disse-me isto ao finalizar o instante de prosa, que surgiu após um relato controlado acerca de seu ofício, revelando aquela parte sobre a qual ainda não tinha controle: seu pesadelo. ${ }^{6}$

Segundo Lynch (2004 [1997]), morrer é nossa natureza, e matar é a capacidade que nós, humanos, temos para que as coisas morram, inclusive nós mesmos. O problema é que quando a indignação começa a se esvair,

6 Em algumas conversas, sobretudo nas primeiras, o relato testemunhal ou biográfico abarcava a maior parte do diálogo. Com o passar do tempo, e dos encontros, a prosa apareceu, misturada com elementos correspondentes ao relato testemunhal distanciado, categorizado sinteticamente por Crapanzano (1994) como correspondente às histórias de guerra, nas quais alguns eventos começam a ser controlados pelo narrador. Destaco, contudo, que a partir dessa combinação, surgem os insights mais dramáticos acerca dos efeitos da violência, que atrelam percursos do sofrimento no luto, na agonia, no bloqueio, no pesadelo. 
as fronteiras entre ser e deixar de ser são apagadas graças a uma tecnologia - relativa à violência - que delata seu funcionamento mediante o terror infligido, mas não permite indagar o que significa devido ao próprio bloqueio que foi gerado.

Do mesmo modo que aconteceu com Nina, ao escrever esta seção do texto, retornei a Urabá em pensamento. As lembranças trouxeram um dos momentos mais transformadores na minha pesquisa em campo. Era meio-dia de domingo e eu caminhava rapidamente para chegar a um encontro. Escutei os disparos. Escutei as motos, e o barulho emitido por elas parecia ainda mais ensurdecedor. Os matadores iam de moto, aproveitaram a mudança do sinal do vermelho para o verde. Muitas balas, mais de 12, como confirmaram depois as plaquinhas policiais da cena do crime. Vi um homem caindo da moto, o sangue escorrendo. Os tiros roçaram-me. Uma multidão surgiu em um segundo. O tráfico fez-se caótico de repente. Crianças, jovens, velhos, mulheres, homens, cachorros aproximaram-se. Ninguém falou nada. Ninguém fez um gesto de reprovação pelo que acabava de acontecer. Eu também não. A vida em Urabá, após oito meses, já tinha conseguido me silenciar. Lembrei naquele instante que várias mulheres contaram-me que os paramilitares proibiam chorar os mortos e matavam aquele que fosse visto pegando os pertences de alguém que acabava de ser assassinado. Podiam até mesmo matar aquele que ousasse participar de certos funerais. As coisas pareciam um pouco diferentes agora, embora permanecessem os efeitos do passado.

As pessoas não paravam de se amontoar ao redor da cena, daquele corpo. E eu não conseguia ficar longe também. Fui me aproximando para ver o "corpo sem vida". Uma atração que ainda não consigo explicar. Os policiais e a equipe de investigação criminal chegaram rapidamente. Eles colocaram limites ao meu avanço. As pessoas continuavam sem manifestar indignação. Somente ouvi algumas ligando por celular para seus amigos e familiares, pois, avaliando o corpo e as roupas, acreditavam ter identificado alguém conhecido. Outros se perguntavam pelo que "ele" teria feito para terminar assim. Eu fingi não ouvir. Esse era meu lado "de cá”, o lado prévio à vida em Urabá. Era um dos meus limites se manifestando contra os princípios da sobrevivência enraizados naquele lugar.

O corpo continuava com o capacete, mas estava solto, como se fosse derreter-se sobre o chão. Quando o vi, foi como se somente estivéssemos ele e eu frente a frente; senti que ali já não havia nada, como disse Mônica. O vazio, minha forma de indignação - em termos de Lynch -, a única possível naquele lugar, foi interior. Senti-me um pouco morta, paralisada por dentro. Alguma coisa foi modificada em mim. O sangue escorrendo pela virilha, as pulseiras e os anéis de ouro na mão direita apresentaram-se como ícones de uma vida que tinha deixado de ser, mas atraíam meu olhar como buscando preencher o vazio. Compreendi porque Lynch diz que o “corpo sem vida” não é ícone; alguns de 
seus componentes são convertidos em ícones na procura de preencher o vazio, de gerar significado. Não sabia, e ainda não sei - não fiz questão de fazer essa indagação - a quem pertenceu aquele "corpo sem vida", relembrando as palavras de Mônica. No entanto, agora, na avaliação das minhas próprias memórias, entendi o que Le Breton (2006 [1997]) quis dizer com a "ausência do outro". Trata-se daquela zona do silêncio na qual falta a palavra do outro e é impossível ver ou entender o mundo sem perceber a lacerante ausência. O silêncio indizível, localizado perto da morte e que, em primeira instância, encarrega-se de abolir a palavra.

Meu relato, escrito a partir do diálogo entre Mônica e Lynch, é, a princípio, testemunhal, pois é uma sucessão de imagens que não dá chance ao leitor de fazer pausas ou perguntas. No entanto, poder-se-ia dizer que foi inspirado em Mônica e Lynch, pessoas com uma compreensão avançada da ausência do outro e da perda. Foi um mergulho no silêncio ensurdecedor que rodeia o cenário da morte, gerando uma confrontação com o indizível, com a palavra que se dilui no silêncio, equiparável a uma forma extrema do grito.

\section{Andrea}

Andrea é uma mulher temerária. Ela, uma liderança que tem trabalhado em prol da verdade, justiça e reparação das vítimas, não parece sentir medo de falar sobre a história do conflito em Urabá, história que ela conhece em detalhes a partir da década de 1980, quando chegou à região. À diferença de Nina ou de Mônica, Andrea nunca marcou um encontro em sua casa. Aliás, nossa relação foi construída a partir de encontros casuais pelas ruas. Vários restaurantes e lanchonetes, então, constituíram-se nossos centros de operações, de conversas intermináveis. Após o nosso primeiro encontro, Andrea começou a ligar com frequência para convidar-me para eventos com a presença de "vítimas da violência”, principalmente. De fato, a minha participação em algumas reuniões em instituições do governo e em eventos organizados por ONG com equipes humanitárias na região foi facilitada pela intermediação de Andrea.

Desde o começo da experiência em Urabá, não quis entrevistar diretamente as "vítimas", na sua grande maioria viúvas, quer dizer, mulheres que, a princípio, buscavam ser reparadas pela morte de seus maridos. A minha pretensão não foi criar um espaço para elas narrarem suas experiências, sobretudo em um lugar em que é tão delicado entrar e construir relações com o conflito ainda vivo. Não queria limitar a experiência e as possibilidades de estabelecer vínculos nem perder a chance de derrubar, por meio da interação, aquela desconfiança primordial.

A partir de meus percursos em Urabá, ou da forma como entrei no campo, sem trabalhar diretamente com organizações de direitos humanos, evitei que a minha pesquisa se tornasse uma incessante busca por vítimas submetidas, por mim, à narração de suas histórias. Foi Das (1995) que veio a contribuir 
para não incorrer na "dupla vitimização" - categoria usada por ela - numa escala micro, ou seja, no nível de minhas interações em campo. A autora argumenta que o sofrimento dos sobreviventes é a ocasião propícia, aproveitada por outros, para aplicar discursos profissionais que terminam sendo usados, de forma hegemônica, com a desculpa de avaliar o estado das vítimas. O Direito e a Medicina têm contribuído para uma teodiceia vinculada ao parens patriae, na qual o sofrimento é a melancolia que garante e mantém a ilusão do Estado. Nesse processo, o sofrimento é isolado, dissociado das vítimas reais. Na minha leitura do enunciado de Veena Das, a busca do Estado pela sua própria autonomia, no seio de processos de verdade, pode terminar com a negação da autonomia ou do direito de consulta das vítimas. Na escala micro, por mim observada, há alguns elementos do sofrimento não dissociado que podem ser identificados nas falas e ações com relação às interdições que impedem a experiência plena do luto.

Foi numa reunião, dirigida por Andrea, com "vítimas" que ela assessora há mais de quatro anos, que vieram à baila aspectos relativos a essa questão. Ocupei o papel de observadora, posição difícil de atingir nessa situação, alcançada graças à confiança que a presença de Andrea irradiou entre o grupo. O fato de Andrea ser "como elas" - por ter sobrevivido "às guerras de Urabá" transformou, até certo ponto, o espaço de conversa, pois das 12 mulheres presentes, quatro quebraram o silêncio. Houve, inclusive, alguns momentos em que ocorreu uma interação delas com Andrea, um momento prosa, de máxima expressividade e mínimo esforço comunicativo, aspecto transcendental, pois o relato biográfico ou testemunhal tende a tomar conta desses encontros. De qualquer maneira, o relato que derrota o silêncio, a princípio biográfico, não começa; ele irrompe, e é tão forte, emocionalmente falando, que anula a resposta de quem está ouvindo. É um estado de surpresa que se prolonga no tempo, gerando um choque. O intérprete nesses casos, em termos de Peirce (1955) e Daniel (1996), localiza-se no plano fenomenológico da atualidade (Secondness), ao qual se associa um caráter emocional e enérgico. A partir de sua vivência entre um grupo de repatriados tâmiles, submetidos a uma violência constante e cumulativa, Daniel salienta que a surpresa se constitui na forma de abrir-se ao mundo. Ela, a surpresa, ajuda a desenhar uma rota para o interior de si.

\section{O GRUPO DE MULHERES DE ANDREA}

Dona Antônia nunca tinha falado sobre sua perda antes; ela começou dizendo que a "vítima" tinha sido um filho que ainda está desaparecido. Depois corrigiu e disse que, na verdade, ela tem três filhos que desapareceram em diferentes anos, todos menores de idade. Disse que antes ela não "era capaz de hablar sobre eso", razão pela qual tinha feito a denúncia apenas cinco anos atrás. Ela disse: 
"Siempre que yo quitaba la tapa, explotaba" ("Toda vez que eu tirava a tampa [da panela], estourava). Após receber os parabéns de Andrea pela sua coragem, ela continuou dizendo: "Yo me la pasaba más privada [desacordada] que otra cosa cuando mis hijos desaparecieron... ya habían matado al papá de ellos. Cuando eso pasó, yo tuve que volver a pie porque ellos no me dejaron coger carro. Eso fue hace 12 años. Ellos se llevaron todo." Após terminar esta frase, Dona Antônia chorou escondendo o rosto e voltou a sentar-se, pois ela tinha ficado em pé durante sua corajosa declaração: uma cadeia de palavras nunca antes ouvida pelas outras participantes do grupo. Dona Antônia nunca tinha "tirado a tampa" na presença daquelas mulheres que são, de qualquer forma, velhas conhecidas e que, além disso, sabem que compartilham questões profundas, como a dor, ainda que não se fale a respeito, sobretudo pelo temor latente dos envolvimentos dos vivos e dos desaparecidos.

Na fala dela, a autoadmiração por ter "tirado a tampa" na frente de outros responde ao mecanismo de busca interior que Daniel relaciona com a surpresa. Adicionalmente, é preciso acrescentar que naquele contexto o choque converteu-se numa possibilidade de transe. Por esta mesma razão, Dona Antônia disse que a maior parte do tempo ela estava desacordada ("privada") ao relembrar o período anterior à realização da denúncia, após o assassinato de seu marido e o desaparecimento de seus filhos. "Estar privado" é uma expressão usada para descrever uma fase do pranto na qual não há mais lágrimas. Segura-se, involuntariamente, a respiração por alguns segundos e perdem-se os "sentidos”. O corpo fica paralisado e a pele adquire uma tonalidade roxa. É um corpo quase inerte. Naquele estado, não somente a palavra é anulada, mas também o pranto.

O estímulo à audácia de Dona Antônia, plasmado nos parabéns dados por Andrea, adota outra dimensão quando se enxerga o percurso por ela realizado, um percurso entre "estar privada" quase o tempo inteiro e sua declaração pública, na qual, no entanto, ela não se coloca como vítima, pois, na sua visão, os filhos são as vítimas porque até hoje eles estão desaparecidos. $\mathrm{Na}$ fase final de sua intervenção, ela não volta ao silêncio indizível: retorna à dor por meio de um pranto que revela o medo herdado. Por isto, é um pranto escondido. Porém, a partir de um estado de quase morte, ela fez a passagem para a sobrevivência.

Carmen, outra das mulheres do grupo, começou a falar dizendo que, quando recebeu a notícia do desaparecimento de seu marido, ficou bebendo água durante 15 dias sem parar. Segundo as versões de testemunhas, o "corpo sem vida" de seu marido foi jogado no rio. Ela disse que não chorava na frente de seus filhos para que eles não a vissem, mas, depois de deixá-los na escola, chorava gritando para desabafar: "[...] sentia que el alma se me estaba desprendiendo... y mis hijos entre todos los huérfanos". A seguir declarou: "este cuerpo es barro, pero la persona nunca muere, está lejos... no ha venido." 
A beleza poética da fala de Carmen demonstra alguns efeitos do pranto contido, substituído, na sobrevivência, pela ingestão exclusiva de água que retrata, de passagem, a necessidade de continuar viva pelos filhos. Penso não ser inapropriado ver a troca de lágrimas por água como um mecanismo metonímico vinculado, por seu turno, à dor vivida. No final das contas, a água também levou a última evidência da vida que foi ceifada. O grito em solidão seria uma solução ao pranto contido, reforçado pela lembrança da possível orfandade dos filhos. Contudo, o grito também é paralelo ao silêncio: em ambos os casos a palavra é abolida. Carmen declara que o corpo é barro. Ainda não faz referência ao "corpo sem vida", pois, justamente, a falta dessa evidência faz com que a morte seja substituída pela distância e pelo vazio do desaparecido que, no caso dela, talvez tenha sido levado pela correnteza do rio.

A essa altura da fala de Carmen, Andrea interveio. Eu, entretanto, lembrava que durante uma de nossas conversas, Andrea tinha me dito que, no caso dos crimes de desaparição forçada e de homicídio - confessados pelos perpetradores da morte -, mas sem o resgate do "corpo sem vida", ela considerava que era melhor acreditar que a pessoa estava mesmo morta para, assim, iniciar o luto, que também deve ter um fim, para continuar vivendo. A ausência do luto, ela sugeriu, é uma forma de sobreviver, de estar meio viva, meio morta - como também o retratava a situação de Nina. Andrea disse a Carmen que o que mais dói é pensar o que fizeram com "ele". Sem esperar, sem deixar o silêncio fazer o papel de intervalo, Carmen disse que ela já foi a muitos enterros ao longo desses anos: "Mi felicidad era enterrar a alguien. No enterré el mío, necesito enterrar los otros." Elsa, outra das mulheres presentes que também quebrou o silêncio naquela ocasião, disse: "A mí me pasó lo mismo. Yo lloraba como si esa persona fuera mi esposo. Me sentía satisfecha haciendo eso... mi angustia era saber si había sido comido por los goleros [urubus]."

A fala de Andrea motivou o momento de máxima emotividade naquela reunião, viabilizado pela troca de emoções entre as três participantes, um momento de comunhão, usando a expressão de Trajano (1984) para caracterizar a prosa. Uma fibra coletiva foi tocada por Andrea quando disse que o que mais dói é pensar o que fizeram com "ele". Esse "ele" anunciado por Andrea, interrompido pela fala de Carmen e Elsa, ainda é uma incógnita para mim, na medida em que é difícil determinar se Andrea estava fazendo referência ao "corpo sem vida" ou ao marido de Carmen nos instantes prévios à agonia. Porém, é preciso levar em consideração que a agonia é um estado especialmente acobertado pelo silêncio, porque denuncia uma participação no ato da morte. Somente em um depoimento a agonia foi mencionada, e até definida, por uma mulher que testemunhou dois massacres. Destaco a importância do depoimento sobre a agonia, pois ela é um mecanismo de redução da linguagem à impotência, outra forma de silêncio. É uma evidência da morte em vida que gera outros pesadelos, similares ao pesadelo de Mônica com os tiros - cujos orifícios no "corpo 
sem vida" são uma das impressões mais fortes de seu ofício: “[... la agonía es un ronquido tan tremendo, es una agonía tan profunda, desesperadora. Eso se queda en el cerebro. Todavía sueño con eso. Sueño con el finado pidiendo auxilio y sueño que ellos me matan [...] siento los impactos de los tiros en mi cuerpo. Me despierto y busco la sangre y no la encuentro."

O sangue pode ser usado como uma prova material de autenticidade (Groebner 2008). Na cena vivida por mim, na seção que descreve o encontro com Mônica, o sangue do "corpo sem vida" do homem da moto, considerado por mim um ícone, terminou comprovando a autenticidade daquela morte. No depoimento citado, a protagonista busca comprovar a autenticidade de seu próprio pesadelo, de uma dor que ainda a acompanha, mediante a busca do sangue em seu corpo ao acordar tremendo pela lembrança da agonia.

Voltando à situação que envolveu Andrea, Carmen e Elsa, a preocupação de Elsa em saber se ele - o "corpo sem vida" se aderirmos à concepção de Mônica - tinha sido comido pelos urubus demonstra a importância, no plano cosmológico, da reintegração do corpo ao mundo dos vivos, a transcendência do resgate das marcas da morte cometida. Neste aspecto, a definição de Lynch (2004 [1997]: 45) do que é um funeral é esclarecedora: é a forma como fechamos o hiato entre "a morte que acontece" e "a morte que é importante". A princípio, "a morte que acontece" cobre, até mesmo, a morte brutalmente cometida. A necessidade de fechar a brecha faz com que a importância da morte deva ser destacada, não per se, mas principalmente pela reintegração ao mundo e pela necessidade social de reproduzir as relações sob outras condições. A necessidade de enterrar "outros" que substituam o "corpo sem vida" perdido é uma resposta à ausência da materialidade da morte. No entanto, esta possibilidade foi negada durante a ocupação e controle dos paramilitares. As pessoas que entravam em contato com os cadáveres depois de um massacre foram chamadas de "moscas", e fala-se, ainda hoje, que elas podiam ser alvo de novas ameaças. Daí a importância do depoimento sobre a agonia citado antes, que também explica a ausência da manifestação de indignação na cena por mim presenciada, um dos efeitos desse amordaçamento social em longo prazo.

Elsa e Carmen criaram estratégias para preencher o vazio da perda, apesar das interdições que pairavam sobre o cotidiano naquela época, nos anos 90 e até os primeiros anos da década de 2000. É difícil determinar os alcances da ameaça naquele período ou a veracidade dos rumores baseados na experiência do terror e do temor latente; porém, a tarefa aqui é evidenciar os efeitos. Além disso, seguindo Chaves (2006), tanto o dito como o não dito portam uma reivindicação de veracidade. Elsa e Carmen, no momento de máxima emotividade, propiciado pela fala de Andrea, indicaram a busca de uma alternativa para vencer o silêncio da morte e a ausência de uma evidência para, desse modo, assimilar o vazio interior. 


\section{O SILÊNCIO E O RETORNO À PALAVRA}

Conforme a caracterização de Daniel (1996), o silêncio poderia ser definido como a impossibilidade de falar, mas com dois sentidos. Por um lado, denota uma brecha entre signo e objeto, constituindo-se num chamado de atenção, uma forma de grito. Mas, por outro lado, o silêncio é uma rejeição da humanidade dos "outros", perpetradores do terror e administradores do medo. É uma recusa a ser totalmente humano, pela rejeição da humanidade daquele que inflige "a morte que importa", não "a morte que acontece". O silêncio, nessas duas vertentes que se misturam durante a experiência violenta e no preâmbulo ao luto, pode ser neutralizado, seguindo a proposta de Daniel, por meio de uma "antropossemiose". Esta noção define-se como a articulação do silêncio, resultado da passagem de uma experiência violenta para a estética do sublime que, por sua vez, pode determinar direcionamentos terapêuticos autônomos. A fala de Carmen, com base no eixo metonímico da água, e a declaração de Dona Antônia sobre a tampa da panela localizam-se na transição em direção ao sublime, permitindo uma incipiente atualização do passado no presente que enfrenta a paralisia e o silêncio, o congelamento da expressão da dor e sua exaltação numa atualidade sem esperança ou numa atualidade que reproduz diariamente a vulnerabilidade social num espectro amplo.

As ações realizadas, tanto por Carmen como por Elsa, participando nos funerais de "outros", chorando para si e pelos "outros", são uma saída antropossemiósica também, na medida em que essas ações estão localizadas no plano da discordância e da interpelação. Neste patamar fenomenológico, a ação é a única manifestação dos sentimentos; ela ajuda a enfrentar a dúvida e a suspeita, a desconfiança, que são, no entanto, elementos constituintes desse "estar no mundo". Por outro lado, a "antropossemiose" pode ser vista como o ponto de interseção, no presente, dos tipos de relato examinados (inacabado, testemunhal ou biográfico, prosa e testemunhal distanciado), visto que a violência é vivida como irrupção ou repetição (Pécaut 2012), mas sempre no presente. Contudo, na interseção dos relatos, o potencial do presente, sua força criativa no imediato, pode conduzir processos terapêuticos que integrem os eventos vividos a uma estrutura temporal das relações cotidianas. Dito de outro modo, o presente é o umbral que deve ser ultrapassado para que o tempo "faça seu trabalho" (Das 2007: 16), como agente e não como representação.

Quebrar o silêncio poderia ser visto como oposição à abolição da palavra, com uma implícita exaltação da palavra, do componente verbal. Mas é preciso lembrar que há gradações do silêncio, do pranto e das próprias alocuções sobre a experiência do medo, do horror e da morte. O relato que quebra o silêncio, com a força que lhe é inerente, gera um choque, mas a sua importância está em ser uma forma de superar o bloqueio que leva ao silêncio indizível. Conforme 
Le Breton (2006 [1997]), a redução do pensamento ao silêncio mediante uma ação de bloqueio exclui outro silêncio, o silêncio interior que permite que a pessoa possa transladar-se até os limites do mundo para achar o sossego necessário, necessário para voltar. A irrupção da fala está relacionada com a quebra da solidão que impede sair de si para relacionar-se com os outros. A partir desta perspectiva, quebrar o silêncio é um ato passível de ser visto como ideal, quando oposto à tortura, por exemplo, na qual a dor é um fim em si mesmo e, por isto, seguindo Daniel, não significa nada. Provavelmente, esse tipo de silêncio será o próprio bloqueio.

$\mathrm{O}$ retorno à palavra é uma esperança de um retorno à vida social. $\mathrm{Na}$ fala de Dona Antônia, e no início da fala de Nina, elas frisam a ideia que os perpetradores do ato de horror - a desaparição, no caso de Dona Antônia, e o assassinato do companheiro de Nina - foram embora "levando tudo", até o teto da casa, nas palavras de Nina. No depoimento de Dona Antônia, esse vazio por terem levado tudo é traduzido na lembrança de ter saído a pé da região, pois "eles" lhe negaram até a possibilidade de sair de carro. O vazio de Dona Antônia é deslocado para a longa e desoladora jornada de seu próprio deslocamento físico. A ruptura termina sendo a única possibilidade de continuar. Na exaltação da jornada a pé de Dona Antônia está presente, igualmente, um traço identificado por Das (1995) nas narrativas de mulheres, quando a pobreza das palavras é tida como uma virtude: elas desviam as histórias que contêm fatos violentos para histórias passíveis de serem ditas.

A esperança de uma "antropossemiose" surgiu em outra voz, a de Dona Maria, naquela mesma reunião orientada por Andrea:

"Yo no dejé que ellos me humillaran porque ellos no dejaban llorar; cuando ellos mataban, uno tenía que enterrar el muerto rapidito. Yo lloré a mi hijo. Fue acusado de prestarle herramienta a un guerrillero... ellos llegaban humillando y yo les dije que yo lloraba porque ellos me habían quitado un tesoro, el hijo mayor y yo amaba mucho a mi hijo. Yo les dije que les agradecía por haber dejado mi hijo en tierra para poder enterrarlo. Yo dije: Gracias a Dios, en primer lugar, y gracias a ustedes, pero lo que ustedes están haciendo no es bueno. ¿Dónde van a llegar? Ellos bajaron la cabeza y se fueron. Después del funeral iba a coger la panga [barco] para Turbo pero no pude porque hubo un encuentro con ellos [um combate]... usted veía ese poco de muertos [monte de mortos] en el río... y eso suena tan bonito... pun, pun, pun, paah... pero no todo lo que es bonito es bueno. Eso es lo que la Biblia dice."

A ação contra a proibição do pranto exercida por Maria demonstra a possibilidade de estabelecer pontes com o sublime. Ela conseguiu reintegrar o "corpo sem vida" a seu círculo; conseguiu enterrar seu filho. Conseguiu enfrentar a 
não humanidade do perpetrador naquele instante, manifestando sua indignação, e soube chorar, ato cuja importância para o luto foi apontada por Lynch: o pranto fecha uma história de amor invertida. Por fim, Maria associa o tiroteio, o som das balas, a um chamado à festa - com fogos - comum naqueles povoados antes da "guerra"; por essa razão, para ela, "isso" soa tão "bonito". $\mathrm{Na}$ sua versão do barulho das balas está implícita uma vontade de transcender o presente, o cenário do horror, mediante uma bela lembrança do passado. Mas o resultado do terror não é ignorado: o cenário do dia seguinte também é retratado por ela.

\section{ALGUMAS CONSIDERAÇÕES FINAIS}

Ao me deparar com o desafio de escrever acerca dos efeitos da violência no cotidiano das pessoas numa região com a presença de diferentes grupos armados que ainda amedrontam o dia a dia, tive que refletir sobre minha própria posição como pesquisadora a partir da tríade violência, tempo, troca. Esse dilema não veio à tona durante o trabalho de campo, pois a minha existência em Urabá começava do zero diariamente. Com o fim da pesquisa e meu retorno a Brasília, voltei a sentir a necessidade de planejar, a médio prazo, um futuro. É sabido como é recorrente o dilema após o retorno do campo que, inclusive, faz parte da subjetividade do etnógrafo. Contudo, o domínio do presente foi a condição da minha experiência de campo e das relações criadas em Urabá, sendo que as experiências violentas, resultado de deslocamentos, desaparições forçadas, massacres, sequestros, torturas e assassinatos, remetem a uma efervescente desconfiança, à banalização da morte violenta e ao ocultamento dos bloqueios a partir de atos que geram estarrecedoras passagens pelo indizível. Os efeitos da violência não se restringiram apenas ao foco da minha indagação etnográfica, mas foram recorrentes inclusive nas condições e nos condicionantes da minha experiência de pesquisa quando, por exemplo, me apresentava em campo às pessoas de Urabá.

No presente artigo construí três relatos principais a partir das relações criadas com três mulheres. Retrospectivamente, vejo que "criei" personagens que, mediante uma determinada narrativa, pudessem transcender o domínio do presente como a marca das minhas relações sociais em Urabá. Escolhi, durante a fase de escrita, plasmar as trajetórias de dois dos relacionamentos mais duradouros que tive, com Nina e Andrea, para assim contrastar esses percursos com um relacionamento mais fugaz, ainda que surpreendente e diferente do padrão identificado em Urabá, como foi o caso do elo com Mônica. Contudo, essa escolha (ou criação de personagens) permitiu destacar a importância do evento, do material bruto da vida social, para refletir, em conjunto com essas mulheres, sobre a morte, sua materialidade, a ausência, o silêncio, a agonia, a vida, a sobrevivência, a sobrevida, o bloqueio, o pesadelo e o luto. 
Os relatos apresentados constituem estratégias de sobrevivência que desafiam, na escrita, os tempos verbais (passado, presente, passado) porque a ênfase dos relatos dos tipos inacabado, testemunhal, testemunhal distanciado e prosa remete, simultaneamente, aos patamares epistemológicos relativos a momento, atualidade e convenção. $\mathrm{O}$ momento relativo à tortura ou à agonia, por exemplo, pode ser expresso no passado, mas continua sendo uma atualidade, um evento que se repete todos os dias, no vívido presente. A memória, desse modo, é condenada a uma lembrança que não cessa. Por outro lado, sem a força do momento e do evento é difícil compreender signos que se tornam convenções sociais e que guiam o futuro, ou que são instrumentalizados para isso. Esse é o caso de alguns esforços pela construção de memória em fases de pós-conflito ou mesmo sem o fim das hostilidades, como tem acontecido na Colômbia. Por essa razão, as narrativas apresentadas advertem sobre a necessidade de voltar ao sentimento e aos eventos para identificar caminhos para construir outras orientações ao mundo, ou seja, outras possibilidades de futuro, mas também de memória. Estou, assim, propondo um possível caminho para desentranhar aspectos acerca da violência que o senso comum esconde e reproduz sem cessar.

\section{BIBLIOGRAFIA}

CHAVES, Christine A., 2006, "Os limites do consentido", em Claudia Fonseca e Jurema Brites (orgs.), Etnografias da Participação. Santa Cruz do Sul, Editora da Universidade de Santa Cruz, 35-58.

CRAPANZANO, Vincent, 1994, "Kevin: on the transfer of emotions", American Anthropologist, 96 (4): 866-885.

DANIEL, Valentine, 1996, Charred Lullabies: Chapters in an Anthropography of Violence. Princeton, Princeton University Press.

DAS, Veena, 1995, Critical Events: An Anthropological Perspective on Contemporary India. Nova Deli, Oxford University Press.

DAS, Veena, 2007, Life and Words: Violence and the Descent into the Ordinary. Berkeley, University of California Press.

GARCÍA, Clara Inés, 1996, Urabá: Región, Actores y Conflicto, 1960-1 1990. Bogotá, CEREC/INER. GROEBNer, Valentín, 2008, Defaced: The Visual Culture of Violence in the Late Middle Ages. Nova Iorque, Zone Books.

HUMAN RIGHTS WATCH, 2010, Herederos de los Paramilitares: La Nueva Cara de la Violencia en Colombia. Nova Iorque, Human Rights Watch.

LE BRETON, David, 2006 [1997], El Silencio: Aproximaciones. Madrid, Sequitur. 
LYNCH, Thomas, 2004 [1997], El Enterrador: La Vida Vista desde el Oficio Fúnebre. Madrid, Alfaguara.

PÉCAUT, Daniel, 2012, Orden y Violencia: Colombia 1930-1953. Medellín, Fondo Editorial Universidad Eafit.

PEIRANO, Mariza, 2001, "A análise antropológica de rituais", em Mariza Peirano (org.), O Dito e o Feito: Ensaios de Antropologia dos Rituais. Rio de Janeiro, Relume Dumará, 17-42. PEIRCE, Charles, 1955, Philosophical Writings of Peirce. Nova Iorque, Dover Publications.

SUÁREZ, Andrés, 2007, Identidades Políticas y Exterminio Recíproco: Masacres y Guerra en Urabá 1991-2001. Medellín, La Carreta, IEPRI (Universidad Nacional de Colombia).

TrAjANO, Wilson, 1984, Músicos e Música no Meio da Travessia. Brasília, Universidade de Brasília, dissertação de mestrado em Antropologia Social. 